\title{
Performance Assessment Handbook for Low-Level Radioactive Waste Disposal Facilities
}

\author{
R. R. Seitz \\ R. S. Garcia \\ K. M. Kostelnik \\ R. J. Starmer
}

February 1992

Idaho National Engineering Laboratory

National Low-Level Waste Program

EG\&G Idaho, Inc.

Idaho Falls, Idaho $\mathbf{8 3 4 1 5}$

\author{
Prepared for the \\ U.S. Department of Energy \\ Office of Environmental Restoration and Waste Management \\ Under DOE Idaho Field Office \\ Contract No. DE-AC07-76ID01570
}




\section{DISCLAIMER}

This report was prepared as an account of work sponsored by an agency of the United States Government. Neither the United States Government nor any agency Thereof, nor any of their employees, makes any warranty, express or implied, or assumes any legal liability or responsibility for the accuracy, completeness, or usefulness of any information, apparatus, product, or process disclosed, or represents that its use would not infringe privately owned rights. Reference herein to any specific commercial product, process, or service by trade name, trademark, manufacturer, or otherwise does not necessarily constitute or imply its endorsement, recommendation, or favoring by the United States Government or any agency thereof. The views and opinions of authors expressed herein do not necessarily state or reflect those of the United States Government or any agency thereof. 


\section{DISCLAIMER}

Portions of this document may be illegible in electronic image products. Images are produced from the best available original document. 


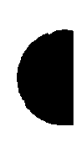

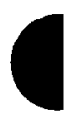

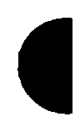




\begin{abstract}
Performance assessments of proposed low-level radioactive waste disposal facilities must be conducted to support licensing. This handbook provides a reference document that can be used as a resource by management and staff responsible for performance assessments. Brief discussions describe the performance assessment process and emphasize selected critical aspects of the process. References are also provided for additional information on many aspects of the performance assessment process. The users' manual for the National Low-Level Waste Management Program's Performance Assessment Center (PAC) on the Idaho National Engineering Laboratory Cray computer is included as Appendix A. The PAC provides users an opportunity to experiment with a number of performance assessment computer codes on a Cray computer. Appendix B describes input data required for 22 performance assessment codes.
\end{abstract}




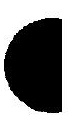

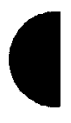

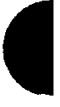




\section{CONTENTS}

ABSTRACT $\ldots \ldots \ldots \ldots \ldots \ldots \ldots \ldots \ldots \ldots \ldots \ldots \ldots \ldots \ldots \ldots \ldots \ldots \ldots$

1. OVERVIEW $\ldots \ldots \ldots \ldots \ldots \ldots \ldots \ldots \ldots \ldots \ldots \ldots \ldots \ldots \ldots \ldots \ldots \ldots \ldots$

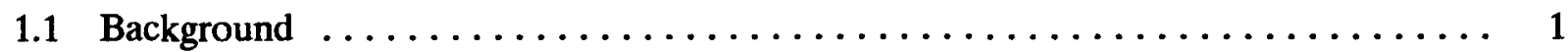

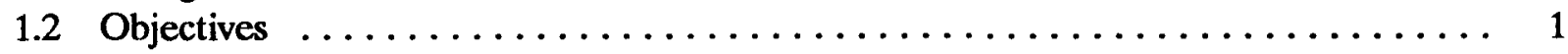

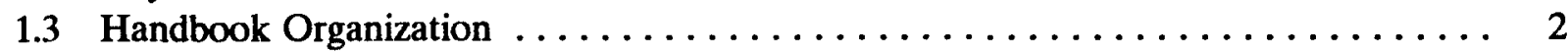

2. PERFORMANCE ASSESSMENT APPROACH $\ldots \ldots \ldots \ldots \ldots \ldots \ldots \ldots$

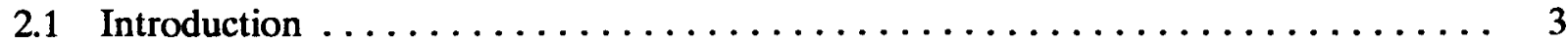

2.2 The Performance Assessment Process $\ldots \ldots \ldots \ldots \ldots \ldots \ldots \ldots \ldots \ldots$

2.2.1 NLLWMP Performance Assessment Guidance . . . . . . . . . . . . . 4

2.2.2 NRC Performance Assessment Methodology $\ldots \ldots \ldots \ldots \ldots \ldots \ldots$

2.2.3 General Performance Assessment Considerations . . . . . . . . . . . . 8

2.3 Performance Assessment Computer Codes and Models . . . . . . . . . . . . 9

2.4 Documentation and Review of Performance Assessments $\ldots \ldots \ldots \ldots \ldots \ldots \ldots$

2.5 Summary $\ldots \ldots \ldots \ldots \ldots \ldots \ldots \ldots \ldots \ldots \ldots \ldots \ldots \ldots \ldots \ldots \ldots$

3. CRITICAL RADIONUCLIDES $\ldots \ldots \ldots \ldots \ldots \ldots \ldots \ldots \ldots \ldots \ldots \ldots \ldots \ldots$

3.1 Radionuclides $\ldots \ldots \ldots \ldots \ldots \ldots \ldots \ldots \ldots \ldots \ldots \ldots \ldots \ldots \ldots \ldots \ldots$

3.2 Bibliography on Radionuclides $\ldots \ldots \ldots \ldots \ldots \ldots \ldots \ldots \ldots \ldots \ldots \ldots \ldots \ldots$

4. PERFORMANCE ASSESSMENT GLOSSARY $\ldots \ldots \ldots \ldots \ldots \ldots \ldots \ldots \ldots$

5. REFERENCES $\ldots \ldots \ldots \ldots \ldots \ldots \ldots \ldots \ldots \ldots \ldots \ldots \ldots \ldots \ldots \ldots \ldots \ldots \ldots \ldots$

Appendix A-DOE/LLW-101, User's Guide for Remote Access of the Performance

Assessment Center . . . . . . . . . . . . . . . . . . . . . .

Appendix B-DOE/LLW-137, Input Data Required for Specific Performance Assessment

Codes 


\section{Performance Assessment Handbook for Low-Level Radioactive Waste Disposal Facilities}

\section{OVERVIEW}

\subsection{Background}

The Low-Level Radioactive Waste Policy Act (PL 96-573) of December 1980 delegated to individual states the responsibility of disposing of commercially generated low-level radioactive wastes (LLW). A state could either develop its own disposal facility for the LLW generated within its borders or enter into a compact with other states and establish a regional disposal facility for the LLW generated within that region. The Low-Level Radioactive Waste Policy Amendments Act of 1985 (PL 99-240) established a series of milestones to ensure that the national compact for LLW disposal progressed as scheduled. One milestone is the submission of a complete license application for LLW disposal by January 1, 1992 (Brown, 1986; PL 99-240).

License applications are required to provide a reasonable assessment of potential radioactive releases via the most significant transport mechanisms for each institutional phase of the facility (US NRC, 1988a). Performance assessment (PA) calculations are intended to show that the proposed near-surface disposal facility is capable of operating within the performance objectives defined in Title 10 of the Code of Federal Regulations Part 61 (10 CFR 61). This regulation emphasizes the need to maintain releases of radioactivity as low as reasonably achievable (ALARA).

The Department of Energy (DOE) established the National Low-Level Waste Management Program (NLLWMP) to provide technical assistance to host states and compact regions developing disposal facilities for low-level radioactive waste. This assistance is developed to fulfill specific host state needs. These needs are expressed to the NLLWMP through the Low-Level Radioactive Waste Forum (Forum) and the Host-State Technical Coordinating Committee (TCC). These two organizations comprise representatives from host states, compact regions, and other Federal agencies.

The TCC and the Forum have identified PA as a topic requiring technical assistance from the NLLWMP. One form of support suggested by the TCC is the development of a handbook on PA. This handbook is a direct result of the technical assistance requested by both the Forum and the TCC.

\subsection{Objectives}

The objective of the Performance Assessment Handbook is to provide a PA reference document for support of siting, designing, and operating a low-level radioactive waste disposal facility. This handbook is not intended to be a comprehensive source of information, rather a reference that can be consulted for general information, specific guidance on selected topics, and guidance on the location of additional information. In this respect, the handbook should complement information provided in the NRC methodology (Kozak et al. 1990) and previous guidance from the National LowLevel Waste Management Program (Case and Otis, 1988). The handbook comprises brief summaries on selected topics and provides references for additional sources of information. 
A second objective of this handbook is to discuss misconceptions regarding the PA process. Emphasis is placed on discussing aspects of the PA process that are overlooked or not apparent to someone with limited experience related to the PA process. For example, use of PA as a tool to reduce characterization and design costs is emphasized.

The NLLWMP has established a Performance Assessment Center (PAC) to provide host states and compact regions access to a number of PA computer codes. A third objective of this handbook is to provide information about accessing the PAC. Many of the more complex PAC computer codes are located on the Idaho National Engineering Laboratory Cray X-MP supercomputer. Representatives of host states and compact regions are given free access and use of the CRAY (PAC codes) by simply submitting an access request form. The PAC provides the opportunity for technical staff to experiment with PA codes on a CRAY computer from their home facilities. A number of PC-based codes are also available through the PAC. The PAC User's Guide (Peterson and Kostelnik, 1990) is included as Appendix A to this handbook.

\subsection{Handbook Organization}

The handbook is organized in the following way: Section 1 contains an overview; Section 2 is a general discussion of the PA process; Section 3 comprises a discussion of radionuclides that are typically of interest in a LLW PA; Section 4 is a glossary of relevant PA terms; and Section 5 is a list of reference materials. The PAC User's Guide is included as Appendix A to this handbook, and Appendix B contains a report that describes input data required for 22 performance codes. 


\section{PERFORMANCE ASSESSMENT APPROACH}

\subsection{Introduction}

Performance assessment (PA) contributes to many aspects of the licensing process. The most common perception is that PA simply involves making compliance calculations to ensure that exposure to the general public from a low-level radioactive waste (LLW) disposal facility is maintained below regulatory limits. This is an improper perception on two accounts: First, it is important to recognize that PA calculations are not simply a compliance tool; they can also be used to reduce the cost of design and site characterization activities during the licensing process. Engineering and design of a disposal system should use PA in the same manner that analysis is used in the design of any other system (i.e., as an inexpensive alternative to physical testing). Second, PA calculations should not be considered absolute predictions. Results should be used to demonstrate that expected doses within a range of uncertainty will be below specified requirements, as opposed to predicting that the dose will be a specific value.

Specific radiological performance objectives are promulgated in 10 CFR 61 to protect the public and inadvertent intruders (Case and Otis, 1988). The following information, as defined in 10 CFR 61, defines objectives and minimum requirements for a performance assessment:

- Description of the site and facility including all information that may impact the site's capability to isolate the wastes from potential receptors, and thus must be addressed in the performance assessment [10 CFR 61.12]

- Analysis requirements for a performance assessment including pathways that must be modeled, and differentiation between site and design features with respect to isolation capability [10 CFR 61.13]

- $\quad$ Protection of the general population from releases of radioactive material by requiring that annual dose equivalents not exceed $25 \mathrm{mrem} / \mathrm{yr}$ to the whole body, $75 \mathrm{mrem} / \mathrm{yr}$ to the thyroid, or $25 \mathrm{mrem} / \mathrm{yr}$ to any other organ of a member of the public [10 CFR 61.41].

The preceding were examples of requirements in 10 CFR 61. Additional requirements may be promulgated in state and local regulations.

The final objective of a PA for a near-surface LLW disposal facility is to demonstrate that potential radiological impacts for each of the human exposure pathways will not violate applicable standards. This involves determining potential pathways and specific receptor locations for human exposure to radionuclides; developing appropriate scenarios for each of the institutional phases of a disposal facility; and maintaining quality assurance and control of all data, computer codes, and documentation. The results of a performance assessment should be used to demonstrate that the expected impacts are expected to be less than the applicable standards. The results should not be used to try to predict the actual impact. This is an important distinction that results from the uncertainties inherent in performance assessment calculations. 
Because of the large data requirements and uncertainties associated with subsurface processes, the PA process is typically not completed in one attempt. Performance assessment is an iterative process and designs, pathways, and models will typically be updated as new results and data are obtained. Defensible data and PA calculations contribute to an efficient siting and licensing program and are an essential element of a final license application for a LLW disposal facility (US NRC, 1988a).

The following sections discuss the PA process including the complementary methodologies prepared for the NLLWMP and the NRC, modeling considerations, and commonly overlooked aspects of the PA process that deserve additional emphasis. Next, a discussion of topics related to computer codes used for PAs is provided. Finally, the NRC review process including minimum PA requirements for a license application is discussed.

\subsection{The Performance Assessment Process}

The NLLWMP provides an approach for conducting radiological PAs (Case and Otis, 1988). This NLLWMP document provides a broad perspective on PA calculations and the interactions of PAs with data collection and design considerations. NRC-sponsored guidance on PAs prepared for commercial LLW disposal is provided in an overview document (Kozak et al. 1990a) and a five volume background information document (Shipers 1989; Shipers and Harlan 1989; Kozak et al. 1989b; Kozak et al. 1989a; 1990b). These documents outline the approach NRC will use to independently oversee PA calculations for disposal sites.

Each of the documents makes important contributions regarding the PA process. While the NRC documents provide greater detail about the specific aspects of modeling exposure pathways, the NLLWMP document is a higher-level discussion that provides a broad perspective of the PA process. Issues such as the iterative nature of the process and the importance of the data collection aspects of the process are emphasized in the NLLWMP document.

The following sections discuss different aspects of the PA process. The NLLWMP document is summarized first to provide a higher-level perspective. Next, a background is given on the pathways and scenarios discussed in the NRC methodology. The remaining discussions emphasize critical PA topics, some of which are discussed in the NLLWMP and (or) other NRC documents. A primary topic of discussion relates to how PA can be used to reduce characterization costs associated with licensing a disposal facility.

\subsubsection{NLLWMP Performance Assessment Guidance}

Case and Otis (1988) portray the PA process as "a wheel centered around data collection" (see Figure 1). This is a useful illustration because it emphasizes the iterative nature of PA and the dependence of PA calculations on availability of proper data. Figure 1 provides a basis for the start of a PA. The analyst must recognize that the sequence of activities must remain somewhat flexible, but the general sequence in Figure 1 should be followed for the first set of calculations. Future iterations may not necessarily follow the exact sequence. A brief description of the steps in involved in the PA process is provided in the following paragraphs. 


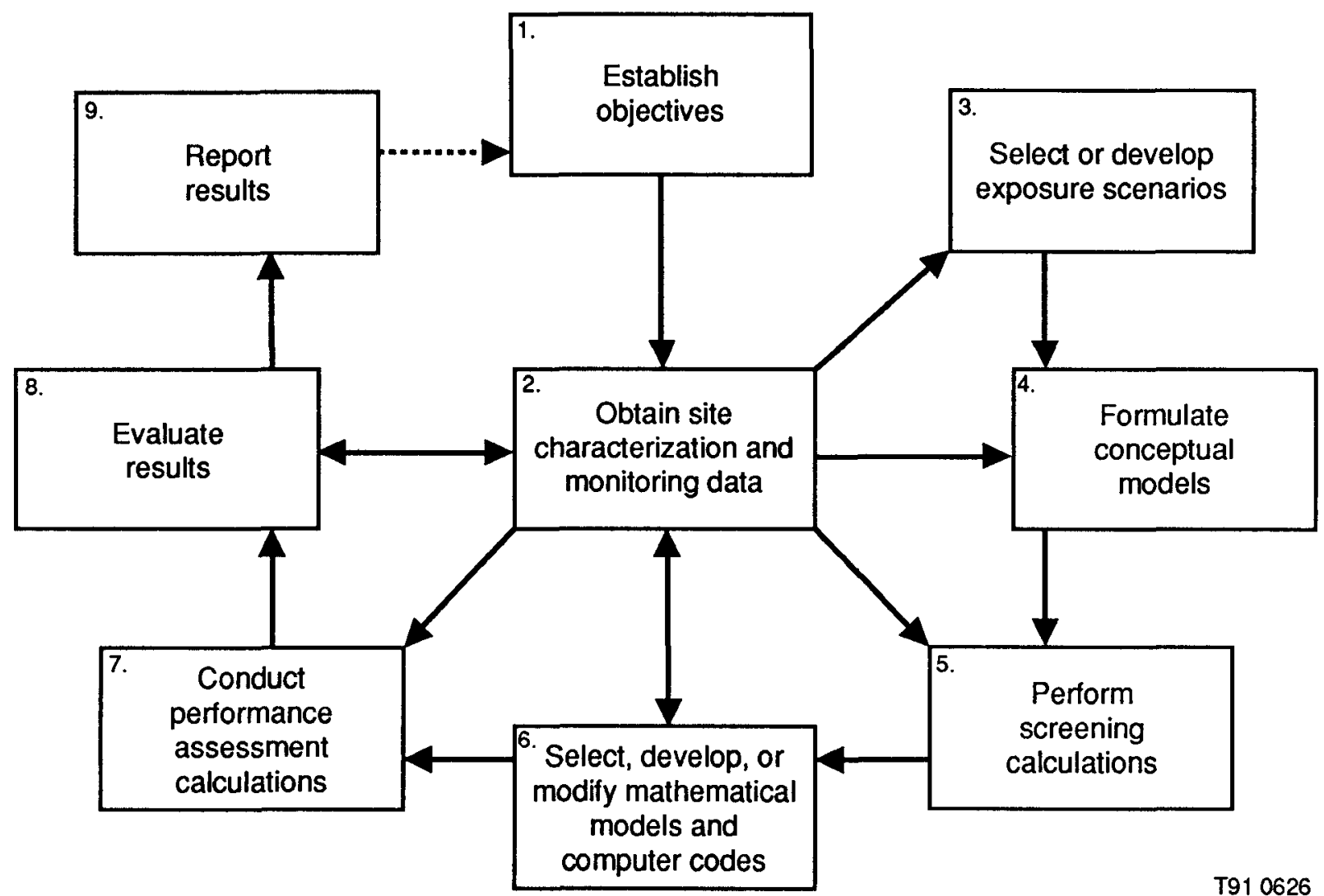

Figure 1. Basis for the start of a PA. 
The first step is to identify the applicable requirements and establish performance objectives. This information should provide a basic guide for the analyst to begin identifying pathways and scenarios to be considered, which are necessary to formulate the conceptual model. The second step is collection and interpretation of site characterization data. Note that this box is the center of the "wheel" emphasizing the critical role data collection plays in the PA process. The site characterization box has two-way interactions with a number of the other steps in the process indicating that data collection is a continuous activity influenced by results of other steps in the PA process. Different approaches to data collection are also discussed later in this section.

Using the performance objectives and site characterization data, the third step involves development of the exposure scenarios. The exposure scenarios should include a set of pathways and processes through which an individual member of the public may be exposed to the buried wastes. Emphasis should be placed on making the exposure scenarios realistic and credible as opposed to worst case. Fourthly, conceptual models that represent the scenarios in terms that are easily translated to the appropriate modeling inputs are then developed. The conceptual models need to be consistent with the level of detail of the available data and the capabilities of the computer codes. Typically, initial PA runs will be conducted with very simple models because of a lack of detailed data. During the development of exposure scenarios and conceptual models, a number of additional data needs are identified.

The fifth step in the PA process entails conducting screening calculations. Screening calculations can be a very beneficial part of the PA process, because in most cases, the final dose prediction is based on contributions from a few key radionuclides. Simple screening calculations (e.g., decay vs. time of institutional control, decay vs. minimum groundwater travel time), conducted with highly conservative models, can eliminate a majority of the radionuclides in the waste inventory from future consideration. Therefore, PA efforts can be focused initially on the limited number of radionuclides that actually contribute to the predicted dose.

Following the screening calculations, the sixth step is that computer codes and modeling approaches that account for more realistic conditions are selected for use with the radionuclides that were not screened. Computer codes should be selected for their capability to model conditions at the given site, and in some cases, it may. be necessary to modify an existing code to model conditions at that site. Because of the site-specific nature of a PA (especially groundwater), it is difficult to recommend one computer code for PA use at all sites. The seventh step is to conduct PA calculations with the selected models. Calculation results are then evaluated to identify dominant processes and areas where future data may be required, and the calculation results are compared with the objectives. The final step is to report the results and discuss deficiencies.

\subsubsection{NRC Performance Assessment Methodology}

The NRC's PA methodology has been structured into a five-step process. In contrast to the higher-level overview of the Case and Otis (1988) guidance, the NRC PA methodology focuses on the pathways and scenarios considered in a PA and the computer codes used as modeling tools for a PA. The steps of the NRC methodology are as follows:

- Identification of Potential Exposure Pathways 
- Assessment of Relative Significance of Migration and Exposure Pathways

- Selection and Integration of Assessment Models

- Selection of Computer Codes that Implement Models

- Implementation of Computer Codes and Assessment.

The essence of these five steps is similar to steps 3-5 in the approach proposed by Case and Otis (1988). It should also be noted that the NRC is currently in the process of producing additional guidance for specific aspects of PAs. Guidance is expected to be issued in late FY-92 or FY-93. A brief description of the five steps is provided in the following paragraphs.

The details of the five-step process are discussed in a five volume NUREG/CR report entitled, Background Information for the Development of a Low-Level Waste Performance Assessment Methodology, NUREG/CR-5453, SAND89-2509, Vol. 1-5 (1989-1990). In the report, the exposure pathways analyzed in the first two steps are developed for a generic site, and are based on a qualitative ranking of both the likelihood of migration occurring along the pathway, and the expected exposure consequence of the pathway. It is important to recognize that pathway analysis for a generic site should not be assumed to represent the ranking of pathways that will be predicted in an analysis for a specific site. However, a general description of the approach that is used for such analyses can be provided in a generic study.

Development of potential exposure pathways and scenarios is an important part of modeling the disposal system and should be considered during the site characterization phase. Detailed lists of exposure pathways that should be addressed by a PA are included in the NRC methodology report. Typical scenarios are also presented in NUREG-1199, Standard Format and Content of a License Application for a Low-Level Radioactive Waste Disposal Facility. However, site-specific scenarios must also be considered. The most relevant exposure scenarios must then be expanded for each of the facility's institutional phases to form a simple descriptive representation (conceptual model) of the disposal facility (Starmer, 1988; Starmer et al., 1988).

Proper selection and integration of assessment models is essential to the activity of assessing exposure pathway consequences. Models should be selected based on the ability to represent sitespecific phenomena such as source-term release, groundwater flow and transport, airborne transport, surface water transport, uptake through the food chain, and dosimetry. A successful code implementation phase is one in which the computer codes are demonstrated to be capable of representing the site-specific conceptual model of the physical and chemical system.

In general, the NRC has advocated the use of reasonably conservative and defensible models for a PA (Starmer, 1988; Starmer et al., 1988). Thus, analytical techniques (i.e., analytic and pseudoanalytic solutions) are included among the analysis methods suggested in the methodology and are preferred over numerical approximations (i.e., finite difference, finite element, etc.) when simplified models are adequate. It is clear that some pathways, notably groundwater, will likely require more complex models. To facilitate this need, a two-stage modeling approach can be used. For example, a detailed characterization (process) model may be used to predict the velocity components of flow in an aquifer. This velocity is then input into a system (multiple pathway) model to calculate the 
remaining dose that results from contaminated groundwater. Such an approach allows the results to be reviewed at a higher level with documentation available upon request for the more detailed calculations. Further discussion of process- and system-level models is provided in Section 2.3.

\subsubsection{General Performance Assessment Considerations}

Topics discussed in this section are commonly overlooked in the context of a PA. Although some of the topics discussed in this section have been mentioned in the preceding sections, additional emphasis was deemed appropriate to reinforce their importance. A primary topic is the iterative nature of PAs. Other topics include as follows: (a) sensitivity analysis, (b) data collection, (c) selection of appropriate models, (d) uncertainty analysis, and (e) quality assurance.

Site-specific data requirements for a PA are extensive and include compiling information on the following: waste characteristics such as activity, volumes, composition, and physical and chemical form; environmental factors including meteorological, geochemical, hydrological, and geologic characteristics; demographic data including eating habits and crop production rates; facility characteristics such as size and type of disposal facility; disposal procedures including package integrity and stabilization techniques; and biotic considerations such as the composition and abundance of plant and animal communities (Case and Otis, 1988; NLLWMP, 1990; also see Appendix B of this report). Collection of site-specific data is one of the most uncertain, time consuming, and expensive aspects of facility design. Thus, reducing the amount of data that must be collected to demonstrate adequate performance can have a significant impact on the cost and timing of the licensing process. The following paragraphs discuss a defensible approach for reducing the site-specific data requirements for a PA.

The first iteration of a PA should be used to limit the amount of data that must be collected to conduct the PA. Relatively simple sensitivity and screening analyses can be used early in the PA process to demonstrate the significance of a given input parameter for a specific problem (Case and Otis 1988; Seitz et al. 1991). In this respect, sensitivity analyses identify the data that have a large impact on the predicted dose, and thus warrant the commitment of resources to obtain additional data. Likewise, data with an insignificant impact on the predicted dose can be identified, and efforts to obtain such data can be minimized. For example, sensitivity analyses can also be used to justify the use of generic data for a given parameter, if results for a wide range of values of the input parameter produce show minimal change in the predicted dose.

Such calculations place the analyst in the position to respond to questions such as "How do you know that the generic value is representative of the site?" Rather than being forced to respond with a statement that the value was assumed to be appropriate, a more concrete response can be provided; the analyst would simply state that the predicted dose was insensitive to changes in the parameter over the expected range of values, and thus, the specific value selected for the parameter within that range is not important.

An illustration of the iterative nature of PA is the use of increasingly complex analysis techniques for each stage of the calculations. In the initial stages, simple hand calculations may provide enough justification to eliminate some pathways and radionuclides from consideration: Such a screening approach will minimize the amount of analyses that would require more detailed modeling. Code selection should ultimately be governed by the identified pathways, site-specific 
processes, quantity and quality of available data, and code capabilities. The use of established codes, if applicable to a specific site, is generally recommended over the development of a new code for each disposal facility. Furthermore, a PA conducted with a highly sophisticated model is not necessarily considered better than a PA conducted with a simple model. In fact, it is preferable to maintain consistency between the modeling complexity and the quantity and quality of available data.

A study conducted during development of the PA methodology for the NRC made code recommendations for use in modeling the processes of interest when conducting a PA. The recommendations should be considered positive reviews of the codes' use for a PA. It is important to note that a National Academy of Sciences Panel has stated that regulatory bodies should not specify computer codes to be used by others in assessment calculations (National Research Council, 1990). Thus, code selection for a given site should still be based on site-specific requirements and the codes in the NRC methodology should be not be considered mandatory for a license application to be approved.

The nature of approximations in PA models and environmental and demographic parameters used as inputs introduces a large amount of uncertainty into PA calculations (Bonano and Cranwell, 1988; Maheras and Kotecki, 1990). Performance assessment calculations, therefore, should not be viewed as absolute. Uncertainty associated with input data leads to uncertainty in the output (parameter uncertainty). Uncertainty is inherent when predicting future events and processes (scenario uncertainty). Translating the subjective conceptual models into mathematical codes introduces additional uncertainty (modeling uncertainty) because mathematical descriptions will necessarily include various assumptions. An uncertainty analysis should be performed to quantify the inherent confidence of the calculated results. Examples of sensitivity and uncertainty analysis techniques are included in Seitz et al. (1991).

A thorough quality assurance (QA) program should also be established and maintained throughout the PA process (US NRC, 1988a). This QA program should provide guidance for collecting, managing, and analyzing data as well as for documenting procedures and analyses (US NRC, 1988a). Analyses should be conducted in a manner that is reproducible and traceable (i.e., input files and source code should be traceable and the analyst should be able to reproduce the results). National Research Council (1990), Seitz et al. (1990), Van Der Heijde (1987), Wilkinson and Runkle (1986), and Silling (1983) provide guidance for testing and documenting PA software.

\subsection{Performance Assessment Computer Codes and Models}

A wide variety of PA computer codes are available for use. The purpose of this section is to provide some background on PA codes and how the different types of codes are used during the process. Specific information presented in this section includes summary descriptions of process- and system-level codes and solution techniques implemented in PA codes. Appendix B to this report describes input data required for 22 performance assessment codes.

Performance assessment codes are often differentiated according to their specific capabilities (Starmer et al. 1988; Case et al. 1989). For example, PA codes can be classified as either characterization (process) or system-level codes (Starmer et al. 1988). Characterization (process) codes are specialized codes dealing with a particular component of the disposal system (e.g., groundwater flow and transport), while the more generalized system-level codes integrate several 
processes involved in the system (e.g., groundwater flow and transport, irrigation, plant uptake and consumption, and internal dosimetry).

System-level codes typically use more simplistic, and thus, generally more conservative representations of system behavior. Initially, a system-level approach can provide a conservative approximation of the performance of a proposed LLW disposal facility. Such modeling efforts are useful during the site characterization and screening phases of the PA process, when less site-specific data will be available. System-level models also provide a relatively straight-forward set of calculations that provide a basis for the demonstration of compliance. Examples of system-level codes include PATHRAE (Rogers and Hung, 1987a), PRESTO-CPG (Rogers and Hung, 1987b), and GENII (Napier, 1988).

A more data-intensive modeling effort may eventually be necessary to fully understand specific aspects of disposal system performance (Starmer et al., 1988). Process-level codes model physical processes at a more mechanistic level based on fundamental principles of physics and mathematics. Modeling in this manner allows for specific phenomena to be simulated in more detail. The application of process-level codes usually requires more detailed, site-specific input parameters to produce an adequate representation of system performance. If used properly, process-level codes, as opposed to system-level codes, tend to yield less conservative results. For example, three-dimensional groundwater codes may be necessary to accurately characterize the hydrologic portion of the system. However, use of sophisticated process-level models must be supported by a corresponding set of site-specific data consistent with the requirements of the code.

Various phenomena are routinely modeled with process-level codes, including infiltration, container degradation, and flow and transport in saturated and unsaturated porous media - which are difficult to represent. The results from the process-level codes (e.g., velocity components, recharge rates) are then used as inputs for a system-level model. Examples of codes in this category include as follows: PORFLO-3 (Sagar and Runchal, 1990 and Runchal and Sagar, 1989), TRACR3D (Travis, 1984), VAM2D (Huyakorn, 1989), PORFLO (Runchal et al., 1985), UNSAT-H (Fayer and Jones, 1990), and BLT (Suen and Sullivan, 1990).

There are essentially three solution techniques used during a PA and they may reside within the realm of process-level or system-level analysis. The three types of mathematical models are analytical, semi-analytical, and discrete numerical. A brief discussion of each technique is provided in the following paragraphs.

Analytical models are those that possess a closed form solution that can readily be evaluated by hand or calculator. Semi-analytical models generally fall under the same constraints of analytical models, with the exception that their solutions are extremely difficult to compute by hand or calculator, or without a handbook of special mathematical functions. Generally, these techniques are only applicable to a simplified representation of the physical and chemical system. Thus, these two solution techniques are typically used in the more global system-level codes. The codes implementing these solutions typically yield more conservative results and are easier to run and understand than numerical codes.

Discrete numerical codes use numerical approximations of the governing equations for individual or coupled processes. Solving these approximations requires numerous repetitive 
calculations, and are most efficiently solved by a computer. Such codes are more versatile and can be used to model more complex (and generally less conservative) representations of specific aspects of the physical system. However, use of these codes becomes as much an art as a science and requires expertise in computer programming and numerical analysis techniques, a solid understanding of the processes being modeled, as well as experience with existing codes that solve such problems.

Codes that can be used for various aspects of a PA are discussed in a report prepared for the NLLWMP (Case et al. 1989). Computer codes that are accessible through the NLLWMP Performance Assessment Center are discussed in a report by Peterson and Kostelnik (1990). This report is included as an appendix to the handbook. Information regarding PA codes and a sample application for the groundwater pathway is also included in Kozak et al. (1990). Till and Meyer (1983) provide excellent information regarding radiological assessment and semi-analytical and analytical tools. Additional codes are also discussed in Appendix B to this report. Detailed discussion of numerical methods used in process-level codes can be found in Huyakorn and Pinder (1983) or Fletcher (1988).

\subsection{Documentation and Review of Performance Assessments}

Demonstration of regulatory compliance is the license applicant's responsibility. Two documents have been produced by the NRC regarding the contents and review criteria for a license application (NRC, 1988a; NRC, 1988b). NUREG-1199, Standard Format and Content of a License Application for a Low-Level Radioactive Waste Disposal Facility, provides a format for the material to be presented in a Safety Analysis Report. Section 6 of NUREG-1199 includes a detailed discussion of the information necessary to document a safety (performance) assessment.

The NRC or the appropriate Agreement State agency will review PAs to determine the adequacy of regulatory compliance for the proposed facility. The NRC provides guidance on their PA review process in Standard Review Plan for Review of a License Application for a Low-Level Radioactive Waste Disposal Facility, NUREG-1200, Rev. 1. Section 6 of NUREG-1200 outlines the review criteria for the different elements of a Safety Assessment. Examples of topics addressed in the review process include validity of assumptions; adequacy of conceptual models for representation of site-specific processes; justification, documentation, verification, and calibration of numerical models; and appropriateness of balance between conservatism and realism in the assessment calculations with respect to the performance objectives.

\subsection{Summary}

This section contains a discussion of approaches for conducting a performance assessment and computer codes used for performance assessment. Approaches prepared for the NLLWMP and the NRC were discussed. The NLLWMP approach provides more perspective on the role of performance assessment in the overall characterization and design process, while the NRC approach focuses more on the actual modeling aspects of performance assessment. A number of common misperceptions about the PA process were also discussed.

A common perception is that PA is a prediction of facility performance that is conducted after site characterization and design are complete. An analyst must understand that due to the 
uncertainties involved, the goal of a PA for a LLW disposal facility is not to predict actual performance of the facility. The goal is to demonstrate that a facility will perform within the performance objectives of 10 CFR 61 and any other applicable state or local regulations. Thus, it is more of a bounding analysis that should be conservative. Furthermore, it is important to recognize that PA is an integral part of an efficient site characterization and design process and not just a compliance tool. Through the use of sensitivity analyses, PA can help focus efforts on characterization and design parameters that have the most critical impacts on the final results. As with the design of any high-tech system, modeling is an inexpensive alternative to physical testing.

Evaluation of the conceptual model of the facility and site should involve the use of appropriate computer codes and site-specific data. Code selection for a PA should be based on the capability of a code to model site-specific conditions. Generally, a single code will not be capable of simulating all relevant scenarios. Compliance calculations may be conducted using a single, systemlevel code. However, supporting calculations to determine selected inputs to the system-level code (e.g., groundwater velocities) may be conducted using a process-level code. In this respect, various levels of modeling are typically necessary to fully evaluate the performance of each LLW disposal facility.

During site characterization, a lack of sufficient data forces the establishment of various assumptions. At this preliminary stage, system-level codes or even hand-calculations are useful for screening calculations to limit the number of radionuclides and pathways that must be considered in detail during later iterations of the PA process. As data collection progresses, more specific process-level codes may be used to provide greater understanding of specific pathways and components. Using multiple codes and coupling various models together provides a more comprehensive evaluation of the complex processes associated with LLW disposal facilities. The final calculations and supporting site-specific data used in support of a license application must be defensible and understandable. Furthermore, the quality and quantity of site-specific data should be consistent with the level of model used for the analysis. 


\section{CRITICAL RADIONUCLIDES}

Performance assessment is the estimation of transport of radionuclides released from low-level radioactive waste to a human receptor and estimation of the resulting health impact. This section of the Performance Assessment Handbook presents a summary description of the radionuclides most often found to be of concern for radioactive waste management, listed according to atomic number. The most important radionuclides of a given site and facility will vary; however, generic analyses suggest that the radionuclides discussed here are among the radionuclides of most concern to health, safety, and the environment. The summary of each radionuclide serves as a quick reference to important characteristics. The selected bibliography in section 3.2 provides references that contain more detailed information on each radionuclide and on such subjects as the nature of low-level radioactive waste, waste likely to contain various radionuclides, behavior of radionuclides in the geosphere, and health impacts of the various radionuclides. These documents also provide information on radionuclides not summarized here.

Basic nuclear physics data is provided to help understand the production and decay of the isotope. This is provided as basic background information and as an indicator of the potential for radiotoxicity. The information on chemical form concentrates on possible existing or future waste form to be found in the environment. General textbooks on geochemistry and the very specific literature of low-level waste geochemistry should be consulted for more information. The chemical behavior of the various radionuclides in the environment is a complicated and often the controlling aspect of health, safety, and environmental impacts. The waste stream information provided is very general in nature, and several references are provided that can provide more detailed information. The information in NUREG-1418 is the most up-to-date information on waste actually being disposed of in commercial facilities, but the information and insights of NUREG-0456 should not be ignored.

Studies for the Environmental Impact Statement (EIS) processes supporting the promulgation of 10 CFR Part 61, including the studies which provided the basis for the Part 61 waste classification system (\$61.55), demonstrated that the major pathway for post-closure exposure of the public is the groundwater pathway. Direct exposure of workers and the potential for exposure of an inadvertent intruder increased the importance of other pathways somewhat. This makes the complicated behavior of some radionuclides in the environment, particularly in groundwater, even more important to estimating potential impact. Finally, information is included on the health hazards associated with each radionuclide. For some radionuclides, short term chemical toxicity and chemical carcinogenicity effects may far outweigh the long-term dangers from radiation-induced cancer. 


\subsection{Radionuclides}

RADIONUCLIDE NAME:

HALF-LIFE:

PRIMARY RADIATIONS

AND ENERGIES:

DAUGHTER PRODUCTS:

MAJOR CHEMICAL FORMS: Tritiated water (HTO)

PRODUCTION METHODS: $\quad$ Fission ${ }^{6} \mathrm{Li}(n, \alpha)$

WASTE STREAMS:

\section{MAJOR ENVIRONMENTAL}

PATHWAY:

Tritium $\left({ }^{3} \mathrm{H},{ }^{\mathrm{N}} \mathrm{T}^{\mathrm{n}}\right)$

12.3 years

Beta, $18.6 \mathrm{keV} \max$ water contaminated trash
Helium-3 $\left({ }^{3} \mathrm{He}\right)$--> stable

Nuclear power plants --> Any waste streams containing coolant

Medical and academic institutions --> Tracers in biological studies usually containing scintillation fluid, tracers in hydrology studies, solid low-level tritium waste in the form of targets and

Industrial --> Others forms are signs and watch dials

Groundwater (tritiated water, HTO and labeled organic compounds)

Air (tritiated gas, HTO)

Easily moves through soil and is absorbed easily by plants

Ingestion and inhalation, internal exposure 
RADIONUCLIDE NAME:

HALF-LIFE:

PRIMARY RADIATIONS

AND ENERGIES:

DAUGHTER PRODUCTS:

MAJOR CHEMICAL FORMS:

PRODUCTION METHODS:

WASTE STREAMS:

MAJOR ENVIRONMENTAL PATHWAY:

HEALTH HAZARDS:
Carbon-14 $\left({ }^{14} \mathrm{C}\right)$

5,730 years

beta, $156 \mathrm{keV}$ max

Nitrogen-14 $\left({ }^{14} \mathrm{~N}\right)-->$ Stable

carbon dioxide $\left({ }^{14} \mathrm{CO}_{2}\right)$, methane $\left({ }^{14} \mathrm{CH}_{4}\right)$, bicarbonate $\left(\mathrm{H}^{14} \mathrm{CO}_{3}\right)$, and elemental carbon $\left({ }^{14} \mathrm{C}\right)$ in activated metals

Naturally occurring; neutron activation of stable nitrogen-14 $\left({ }^{14} \mathrm{~N}(\mathrm{n}, \mathrm{p})\right)$

Nuclear power plants --> Activated metals, ion-exchange resins, precoat filters, cartridge filters, concentrated liquid wastes, trash, dry active waste, and non-fuel reactor parts medical and academic institutions $-\rightarrow$ Trash, liquid scintillation vials, absorbed aqueous and organic liquids, biological wastes resulting from use of ${ }^{14} \mathrm{C}$ labeled compounds

Atmospheric transport (natural activation of atmospheric ${ }^{14} \mathrm{~N}$ by cosmic ray interaction, ${ }^{14} \mathrm{CO}_{2}$ and ${ }^{14} \mathrm{CH}_{4}$ released to the atmosphere); uptake of ${ }^{14} \mathrm{CO}_{2}$ by plants; carbon-14 bicarbonate and carbonate transport by groundwater; carbon-14 in activated metals from reactor components

Carbon-14 tends to accumulate in bone tissue; inhaled ${ }^{14} \mathrm{CO}_{2}$ enters the bloodstream and reaches an equilibrium with $\mathrm{CO}_{2}$ already in the bloodstream 
RADIONUCLIDE NAME:

HALF-LIFE:

PRIMARY RADIATIONS

AND ENERGIES:

DAUGHTER PRODUCTS:

MAJOR CHEMICAL FORMS:

PRODUCTION METHODS:

WASTE STREAMS:

MAJOR ENVIRONMENTAL

PATHWAY:

HEALTH HAZARDS:
Nickel-59 $\left({ }^{59} \mathrm{Ni}\right)$

76,000 years

Decays by electron capture (Co x-rays, continuous bremsstrahlung to $1.06 \mathrm{MeV}$ )

Cobalt-59 $\left({ }^{59} \mathrm{Co}\right)-->$ Stable

$\mathrm{Ni}^{++}, \mathrm{NiOH}^{-}, \mathrm{NiCl}_{2}^{\circ}, \mathrm{Ni}(\mathrm{OH})_{2}, \mathrm{NiS}(\mathrm{s}), \mathrm{NiCO}_{3}$

Produced by neutron bombardment of stable nickel-58

present in reactor hardware, including alloying agents and trace impurities

Nuclear power plants --> Ion-exchange resins, precoat filters, cartridge filters, concentrated liquid wastes, trash, dry active waste, non-fuel reactor components

Groundwater

Ingestion, internal exposure 
RADIONUCLIDE NAME:

HALF-LIFE:

PRIMARY RADIATIONS

AND ENERGIES:

DAUGHTER PRODUCTS:

MAJOR CHEMICAL FORMS:

PRODUCTION METHODS:

WASTE STREAMS:

MAJOR ENVIRONMENTAL PATHWAY:

HEALTH HAZARDS:
Cobalt $-60\left({ }^{60} \mathrm{Co}\right)$

5.272 years

Beta, $318 \mathrm{keV}$ max gamma, 1.3325 Mev (100\%), 1.1732 MeV (100\%)

Nickel-60 $\left({ }^{60} \mathrm{Ni}\right)-->$ Stable

See ${ }^{59} \mathrm{Ni}$, i.e. ${ }^{60} \mathrm{Co}$ takes the same chemical forms as does element ${ }^{59} \mathrm{Ni}$

Produced by the neutron activation of cobalt-59

Nuclear power plants --> Ion-exchange resins, concentrated liquids, filter sludge, cartridge filters, trash, dry active waste, and waste from decommissioning medical and academic institutions -> Teletherapy units, radiography cameras, and geological and biological studies

Groundwater (highly retarded by sorptive processes)

Direct exposure due to gamma emissions, ingestion and internal exposure 
RADIONUCLIDE NAME: Nickel-63 $\left({ }^{63} \mathrm{Ni}\right)$

HALF-LIFE:

100 years

PRIMARY RADIATIONS

AND ENERGIES:

Beta, $65.9 \mathrm{keV}$ max

DAUGHTER PRODUCTS:

Copper-63 $\left({ }^{63} \mathrm{Cu}\right)-->$ Stable

MAJOR CHEMICAL FORMS: See ${ }^{59} \mathrm{Ni}$, i.e. ${ }^{63} \mathrm{Ni}$ takes the same chemical forms as does element ${ }^{59} \mathrm{Ni}$

PRODUCTION METHODS: Produced by the neutron activation of nickel-62 in structural components of nuclear reactors, accelerators, and neutron encapsulating devices

WASTE STREAMS:

Nuclear power plants --> Ion-exchange resins, concentrated liquids, activated metals, filter sludge, cartridge filters, trash, and decommissioned waste accelerators and academic institutions -> Structural components that had undergone neutron activation consumer products such as smoke detectors and electron tubes

MAJOR ENVIRONMENTAL PATHWAY:

Groundwater

HEALTH HAZARDS:

Ingestion, internal exposure 
RADIONUCLIDE NAME: Strontium-90 $\left({ }^{90} \mathrm{Sr}\right)$

HALF-LIFE:

29.1 years

PRIMARY RADIATIONS

AND ENERGIES:

Beta, $546 \mathrm{keV} \max$

DAUGHTER PRODUCTS: Yttrium-90 $\left({ }^{90} \mathrm{Y}\right)$--> Half-life: 64 hours

Emissions: beta, $2.28 \mathrm{MeV} \max$

MAJOR CHEMICAL FORMS: $\quad \mathrm{Sr}^{++}, \mathrm{SrCO}_{3}(\mathrm{~s})$

PRODUCTION METHODS: $\quad$ Fission product

WASTE STREAMS:

Nuclear power plants --> Ion-exchange resins, precoat filters, cartridge filters, concentrated liquid wastes, trash, dry active waste, and waste from decommissioning

MAJOR ENVIRONMENTAL

PATHWAY:

Milk, groundwater

HEALTH HAZARDS:

Ingestion and internal exposure from beta emission, "bone seeker" 
RADIONUCLIDE NAME:

HALF-LIFE:

PRIMARY RADIATIONS

AND ENERGIES:

DAUGHTER PRODUCTS:

MAJOR CHEMICAL FORMS:

PRODUCTION METHODS:

WASTE STREAMS:

MAJOR ENVIRONMENTAL

PATHWAY:

HEALTH HAZARDS:
Niobium-94 $\left({ }^{94} \mathrm{Nb}\right)$

20,000 years

Beta, $470 \mathrm{keV}$ max gamma, $871 \mathrm{keV}(100 \%), 703 \mathrm{keV}(100 \%)$

Molybdenum-94 $\left({ }^{94} \mathrm{Mo}\right)$--> Stable

$\mathrm{Nb}(\mathrm{OH})_{5}(\mathbf{s})$

Produced by the neutron activation of niobium-93, the only stable isotope of niobium

Nuclear power plants --> Activation products from reactor system hardware

Air, groundwater (except that adsorption behavior of ${ }^{94} \mathrm{Nb}$ is uncertain, i.e. extent of groundwater pathway is undetermined)

Inhalation and ingestion, internal exposure; direct exposure due to gamma emissions 
RADIONUCLIDE NAME:

HALF-LIFE:

PRIMARY RADIATIONS

AND ENERGIES:

DAUGHTER PRODUCTS:

MAJOR CHEMICAL FORMS:

PRODUCTION METHODS:

WASTE STREAMS:

MAJOR ENVIRONMENTAL PATHWAY:

HEALTH HAZARDS:
Technetium-99 ( $\left.{ }^{99} \mathrm{Tc}\right)$

213,000 years

Beta, $293 \mathrm{keV}$ max

Ruthenium-99 ( $\left.{ }^{99} \mathrm{Ru}\right)$--> Stable

$\mathrm{TcO}_{4-}, \mathrm{Tc}^{4+}, \mathrm{Tc}(\mathrm{OH}) 40, \mathrm{TcO}_{2}(\mathrm{~s})$

Fission product

Nuclear power plants --> Ion-exchange resins, precoat filters, cartridge filters, concentrated liquid wastes, trash, dry active waste, and waste from decommissioning medical and academic institutions --> Molybdenum/technetium generators, biological waste (animal carcasses, tissue, vegetation, and culture media)

$\mathrm{TcO}_{4}$ is very mobile in soil, vegetation, and groundwater under oxidizing conditions; Under reducing conditions, $\mathrm{TcO}_{2}$ or related hydrolyzed $\mathrm{TcO}_{2}$ is the predominant form and both are relatively insoluble

Ingestion and internal exposure from beta emission leads to exposure of the thyroid and gastrointestinal tract. Within 10 hours it redistributes to the stomach and organs with excretory functions, such as kidneys and salivary glands. 
RADIONUCLIDE NAME:

HALF-LIFE:

PRIMARY RADIATIONS

AND ENERGIES:

DAUGHTER PRODUCTS:

MAJOR CHEMICAL FORMS:

PRODUCTION METHODS:

WASTE STREAMS:

MAJOR ENVIRONMENTAL

PATHWAY:

HEALTH HAZARDS:
Iodine-129 $\left({ }^{129} \mathrm{I}\right)$

$16,000,000$ years

Beta, $150 \mathrm{keV}$ max gamma, $40 \mathrm{keV}$ (9\%)

Xenon-129 $\left({ }^{129} \mathrm{Xe}\right)-->$ Stable

Iodide ion $\left(\mathrm{I}^{-}\right)$, iodate ion $\left(\mathrm{IO}_{3}^{-}\right)$

Fission product

Nuclear power plants --> Activated metals, ion-exchange resins, precoat filters, cartridge filters, concentrated liquid wastes, trash, dry active waste

Groundwater (iodide), iodate in the marine environment

Long-term ingestion 
RADIONUCLIDE NAME:

HALF-LIFE:

PRIMARY RADIATIONS

AND ENERGIES:

DAUGHTER PRODUCTS:

MAJOR CHEMICAL FORMS: Ionic cesium $\left(\mathrm{Cs}^{+}\right)$

PRODUCTION METHODS: Fission product

WASTE STREAMS:

MAJOR ENVIRONMENTAL

PATHWAY:

HEALTH HAZARDS:

Cesium-137 $\left({ }^{137} \mathrm{Cs}\right)$

30.17 years
Gamma, $662 \mathrm{keV}$ beta, $1.176 \mathrm{MeV} \max (7 \%), 514 \mathrm{keV} \max$

Barium-137m $\left({ }^{137 m} \mathrm{Ba}\right)$--> Half-life: 2.55 minutes Emissions: gamma, $662 \mathrm{keV}(89 \%)$

Nuclear power plants --> Ion-exchange resins, precoat filters, cartridge filters, concentrated liquid wastes, trash, dry active waste, and waste from decommissioning medical and academic institutions --> Biological wastes (carcasses, tissues, animal bedding excreta, vegetation, and cultural media) industrial processes--> Sealed sources

Groundwater (highly retarded by sorptive processes)

Direct exposure; ingestion, internal exposure 
RADIONUCLIDE NAME: Thorium-230 $\left({ }^{230} \mathrm{Th}\right)$

HALF-LIFE:

75,400 years

PRIMARY RADIATIONS

AND ENERGIES:

Alpha, 4.688 MeV (76\%), 4.621 MeV (24\%)

DAUGHTER PRODUCTS: $\quad$ (Decay chain)

$$
\begin{aligned}
& { }^{230} \mathrm{Th}->{ }^{226} \mathrm{Ra}->{ }^{222} \mathrm{Rn}->{ }^{218} \mathrm{Po}->{ }^{214} \mathrm{~Pb}->{ }^{214} \mathrm{Bi}->{ }^{214} \mathrm{Po}-> \\
& { }^{210} \mathrm{~Pb} \text {-> }{ }^{210} \mathrm{Bi}->{ }^{210} \mathrm{Po}->{ }^{206} \mathrm{~Pb} \text { (Stable) }
\end{aligned}
$$

Ra-226 $\left({ }^{226} \mathrm{Ra}\right) \quad$--> Half-life: 1,600 years

Emissions: alpha, $4.7845 \mathrm{MeV}$ (95\%),

$4.60 \mathrm{MeV} 6 \%$

gamma, $186 \mathrm{keV}(4 \%)$

Rn-222 ( $\left.{ }^{222} \mathrm{Rn}\right)$--> Half-life: 3.8235 days

Emissions: alpha, $5.4897 \mathrm{MeV}(100 \%)$

Po-218 $\left({ }^{218} \mathrm{Po}\right) \rightarrow>$ Half-life: 3.11 minutes

Emissions: alpha, $6.0026 \mathrm{MeV}(100 \%)$

$\mathrm{Pb}-214\left({ }^{214} \mathrm{~Pb}\right) \rightarrow$ Half-life: 26.8 minutes

Emissions: beta, $1.03 \mathrm{MeV}$ max

gamma, $53 \mathrm{keV}(1 \%), 242 \mathrm{keV}$

(4\%), $295 \mathrm{keV}(19 \%), 352$

$\operatorname{keV}(36 \%)$

Bi-214 $\left({ }^{214} \mathrm{Bi}\right) \rightarrow$ Half-life: 19.8 minutes

Emissions: beta, $3.26 \mathrm{MeV}$ max

gamma, $609 \mathrm{keV}(47 \%), 769$

$\mathrm{keV}(5 \%), 935 \mathrm{keV}(3 \%)$,

$1.12 \mathrm{MeV}(17 \%), 1.238 \mathrm{MeV}$

(6\%), $1.378 \mathrm{MeV}(5 \%), 1.40$

$\mathrm{MeV}(4 \%), 1.509 \mathrm{MeV}(2 \%)$,

$1.728 \mathrm{MeV}(3 \%), 1.764 \mathrm{MeV}$

(17\%), $1.848 \mathrm{MeV}(2 \%)$,

$2.117 \mathrm{MeV}(1 \%), 2.204 \mathrm{MeV}$

(5\%), $2.445 \mathrm{MeV}(2 \%)$ 
${ }^{230}$ Th DAUGHTER PRODUCTS: (Continued)

$$
\begin{aligned}
& \text { Po-214 ( } \left.{ }^{214} \mathrm{Po}\right) \text {--> Half-life: } 163.7 \mu \mathrm{sec} \\
& \text { Emissions: alpha, 7.69 MeV (100\%) } \\
& \text { Pb-210 }\left({ }^{210} \mathrm{~Pb}\right) \text {--> Half-life: } 22.3 \text { years } \\
& \text { Emissions: alpha, } 3.72 \mathrm{MeV} \\
& \text { beta, } 61 \mathrm{keV} \max \\
& \text { gamma, } 47 \mathrm{keV} \mathrm{(4 \% )}
\end{aligned}
$$

MAJOR CHEMICAL FORMS: $\quad \mathrm{Th}^{4+}, \mathrm{Th}(\mathrm{OH})_{3} ; \mathrm{Th}\left(\mathrm{HCO}_{3}\right)^{3+}, \mathrm{ThO}_{2}(\mathrm{~s})$

PRODUCTION METHODS: Natural

WASTE STREAMS:

Rare metal processors

thoriated welding rods and manufacture

lamp starters and manufacture

lantern mantles and manufacture

MAJOR ENVIRONMENTAL PATHWAY:

Groundwater, air

HEALTH HAZARDS:

Ingestion, internal dose particularly due to daughters 
RADIONUCLIDE NAME: Neptunium-237 $\left({ }^{237} \mathrm{~Np}\right)$

HALF-LIFE: $\quad 2,140,000$ years

PRIMARY RADIATIONS

AND ENERGIES: $\quad$ Alpha, $4.788 \mathrm{Mev}(75 \%), 4.770 \mathrm{MeV}(12 \%)$

gamma, $29.4 \mathrm{keV}(14 \%), 86.5 \mathrm{kev}(14 \%), 145 \mathrm{keV}(1 \%)$

DAUGHTER PRODUCTS: (Decay chain)

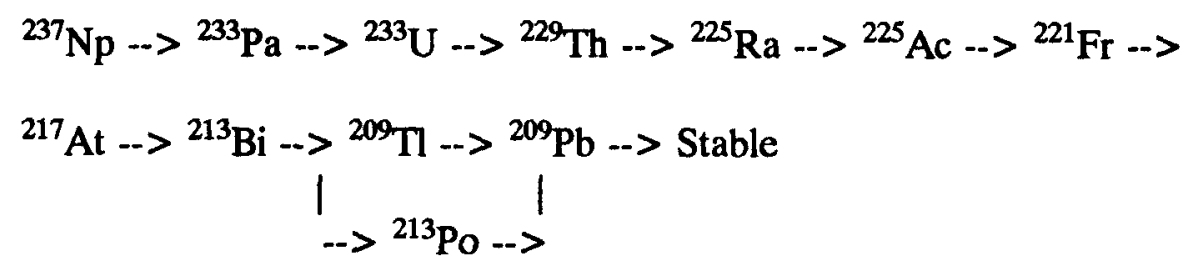

Pa-233 ( $\left.{ }^{233} \mathrm{~Pa}\right)$--> Half-life: 27 days

Emissions: beta, $256 \mathrm{keV} \max$

gamma, $312 \mathrm{keV}(44 \%)$

U-233 $\left({ }^{233} U\right) \quad-->$ Half-life: 159,200 years

Emissions: alpha, $4.824 \mathrm{MeV}(83 \%)$,

$4.783 \mathrm{MeV}(15 \%)$

Th-229 $\left.{ }^{229} \mathrm{Th}\right)$--> Half-life: 7,300 years

Emissions: alpha, 5.05 MeV (7\%), 4.97

$\mathrm{MeV}(10 \%), 4.90 \mathrm{MeV}(11 \%)$,

$4.84 \mathrm{MeV}(58 \%), 4.81 \mathrm{MeV}$

(11\%)

gamma, $137 \mathrm{keV}$ (3\%), 200

$\operatorname{keV}(10 \%)$

Ra-225 ( ${ }^{225} \mathrm{Ra}$ )--> Half-life: 14.8 days

Emissions: beta, $360 \mathrm{keV}$ max

gamma, $40 \mathrm{keV}$ (33\%)

Ac-225 ( $\left.{ }^{225} \mathrm{Ac}\right)$--> Half-life: 10.0 days

Emissions: alpha, $5.83 \mathrm{MeV}$ (54\%), 5.794

$\mathrm{MeV}$ (28\%), $5.73 \mathrm{MeV}$ (10\%) 
${ }^{237}$ Np DAUGHTER PRODUCTS: (Continued)

\author{
Fr-221 $\left({ }^{221} \mathrm{Fr}\right)-->\quad$ Half-life: 4.8 minutes \\ Emissions: alpha, $6.341 \mathrm{MeV}(82 \%)$, \\ 6.126 MeV (15\%) \\ gamma, $218 \mathrm{keV}(14 \%)$ \\ At-217 $\left({ }^{217} \mathrm{At}\right)$--> Half-life: 32.3 msecs \\ Emissions: alpha, $7.069 \mathrm{MeV}(99+\%)$ \\ Bi-213 $\left({ }^{213} \mathrm{Bi}\right)->\quad$ Half-life: 45.6 minutes \\ Emissions: alpha, $5.87 \mathrm{MeV}$ \\ beta, $1.42 \mathrm{MeV}$ max \\ gamma, $440 \mathrm{keV}$ \\ Po-213 ( $\left.{ }^{213} \mathrm{Po}\right)$--> Half-life: $4.2 \mu \mathrm{secs}$ \\ Emissions: alpha, $8.375 \mathrm{MeV}$ \\ T1-209 $\left({ }^{209} \mathrm{Tl}\right)$--> Half-life: 2.2 minutes \\ Emissions: beta, $1.8 \mathrm{MeV}$ max \\ gamma, $156 \mathrm{keV}(100 \%), 117$ \\ $\mathrm{keV}(50 \%), 465 \mathrm{keV}(100 \%)$ \\ Pb-209 $\left({ }^{209} \mathrm{~Pb}\right)-->$ Half-life: 3.25 hours \\ Emissions: beta, $645 \mathrm{keV}$ max
}

MAJOR CHEMICAL FORMS: $\quad \mathrm{NpO}_{2}{ }^{+}, \mathrm{NpO}_{2}(\mathrm{~s})$

PRODUCTION METHODS: $\quad$ Neutron activation of uranium-238 produces uranium-237. ${ }^{237} \mathrm{U}$ emits a beta particle and decays to neptunium-237; another means of production is by double neutron capture of enriched uranium235 , which produces uranium-237, which decays to neptunium-237.

WASTE STREAMS:

Resulting from reprocessing of spent fuel and recycling of uranium and plutonium --> Unsolidified liquid waste, filters, sludge, trash, and waste from decommissioning

MAJOR ENVIRONMENTAL

PATHWAY:

Groundwater (more mobile under oxidizing conditions)

HEALTH HAZARDS:

Ingestion and inhalation, internal exposure 
RADIONUCLIDE NAME: Uranium-235

HALF-LIFE:

$703,800,000$ years

PRIMARY RADIATIONS

AND ENERGIES:

Alpha, 4.58 MeV (8\%), 4.4 MeV (57\%), $4.37 \mathrm{MeV}(8 \%)$

gamma, $143 \mathrm{keV}(11 \%), 185$ (54\%), $204 \mathrm{keV}(5 \%)$

DAUGHTER PRODUCTS: (Decay chain)

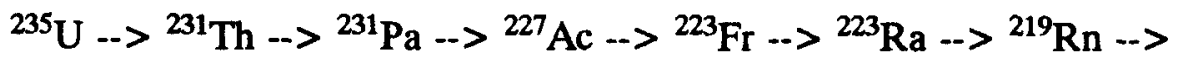

$$
\begin{aligned}
& \text { I } \rightarrow{ }^{227} \mathrm{Th} \rightarrow \\
& { }^{215} \mathrm{Po} \ldots>{ }^{211} \mathrm{~Pb} \ldots>{ }^{211} \mathrm{Bi} \text {--> }{ }^{207} \mathrm{Tl} \text {--> stable } \\
& { }_{-.>}{ }^{211} \text { Po } \rightarrow>
\end{aligned}
$$

Th-231 $\left({ }^{231} \mathrm{Th}\right)$--> Half-life: 25.52 hours

Emissions: beta, $305 \mathrm{keV}$ max

gamma, $25 \mathrm{keV}(2 \%), 84 \mathrm{keV}$ (10\%)

Pa-231 ( $\left.{ }^{231} \mathrm{~Pa}\right)$--> Half-life: 32,800 years

Emissions: alpha, $5.06 \mathrm{MeV}(10 \%), 5.02$

$\mathrm{MeV}(23 \%), 5.01 \mathrm{MeV}(24 \%)$,

$4.95 \mathrm{MeV}(22 \%), 4.73 \mathrm{MeV}$ (11\%)

gamma, $27 \mathrm{keV}(6 \%), 29 \mathrm{keV}$ $(6 \%)$

Ac-227 $\left({ }^{227} \mathrm{Ac}\right)$--> Half-life: 21.773 years

Emissions: alpha, $4.951 \mathrm{MeV}(1.2 \%)$

beta, $44 \mathrm{keV}$ max

Th-227 ( $\left.{ }^{227} \mathrm{Th}\right)-->$ Half-life: 18.72 days

Emissions: alpha, $6.0382 \mathrm{MeV}$ (23\%),

$5.977 \mathrm{MeV}(24 \%), 5.7571 \mathrm{MeV}$

(21\%), $5.72 \mathrm{MeV} 14 \%$ )

gamma, $50 \mathrm{keV}(8 \%), 236 \mathrm{keV}$

(15\%), $310 \mathrm{keV}(8 \%)$ 
${ }^{235}$ U DAUGHTER PRODUCTS: (continued)

Fr-223 $\left({ }^{223} \mathrm{Fr}\right)->\quad$ Half-life: 22.0 minutes

Emissions: beta, $1.17 \mathrm{MeV}$ max

gamma, $50 \mathrm{keV}$ (40\%), 79.8

$\operatorname{keV}(13 \%), 235 \mathrm{keV}(4 \%)$

Ra-223 ( $\left.{ }^{223} \mathrm{Ra}\right)-->$ Half-life: 11.434 days

Emissions: alpha, 5.75 MeV (9\%), 5.71

$\mathrm{MeV}$ (54\%), $5.61 \mathrm{MeV}$ (26\%),

$5.54 \mathrm{MeV}$ (9\%)

gamma, $154 \mathrm{keV}$ (10\%), $269 \mathrm{keV}$ $(10 \%), 330 \mathrm{keV}(6 \%)$

Rn-219 ( $\left.{ }^{219} \mathrm{Rn}\right)-->$ Half-life: 3.96 secs

Emissions: alpha, $6.8193 \mathrm{MeV}(81 \%)$, $6.553 \mathrm{MeV}(11 \%), .425 \mathrm{MeV}(8 \%)$ gamma, $271 \mathrm{keV}(9 \%), 402 \mathrm{keV}$ (5\%)

Po-215 ( $\left.{ }^{215} \mathrm{Po}\right)$--> Half-life: 1.78 msecs

Emissions: alpha, 7.386 MeV (100\%)

gamma, $405 \mathrm{keV}, 427 \mathrm{keV}$

Pb-211 ( $\left.{ }^{211} \mathrm{~Pb}\right)-->$ Half-life: 36.1 minutes

Emissions: beta, $1.38 \mathrm{MeV}$ max

gamma, $405 \mathrm{keV}$ (3.4\%), 832

$\mathrm{keV}(3.4 \%), 427 \mathrm{keV}(1.8 \%)$

Bi-211 $\left({ }^{211} \mathrm{Bi}\right)->\quad$ Half-life: 2.14 minutes

Emissions: alpha, 6.623 MeV (84\%), 6.279

$\mathrm{MeV}(16 \%)$

gamma, $351 \mathrm{keV}(14 \%)$

Po-211 ( $\left.{ }^{211} \mathrm{Po}\right)-->$ Half-life: 0.516 secs

Emissions: alpha, $7.45 \mathrm{MeV}$ (99\%)

Tl-207 $\left({ }^{207} \mathrm{Tl}\right)-->\quad$ Half-life: 4.77 minutes

Emissions: beta, $1.44 \mathrm{MeV}$ max

MAJOR CHEMICAL FORMS: $\quad \mathrm{UO}_{2}{ }^{2+}, \mathrm{U}^{4+}$ complexes, $\mathrm{UO}_{2}{ }^{2+}$ complexes, $\mathrm{UO}_{2+\mathrm{x}}(\mathrm{s}), \mathrm{NaUO}_{4}(\mathrm{~s})$

PRODUCTION METHODS: Natural 
WASTE STREAMS:

Reactor wastes fuel fabrication and $\mathrm{UF}_{6}$ conversion plant wastes rare metal processors

MAJOR ENVIRONMENTAL

PATHWAY:

Groundwater, air

HEALTH HAZARDS:

Ingestion internal dose particularly to bone, lung dose from inhalation, chemical toxicity 
RADIONUCLIDE NAME: Uranium-238

HALF-LIFE:

$4,468,000,000$ years

PRIMARY RADIATIONS

AND ENERGIES:

Alpha, 4.20 MeV (75\%), 4.15 MeV (25\%)

DAUGHTER PRODUCTS: (Decay chain)

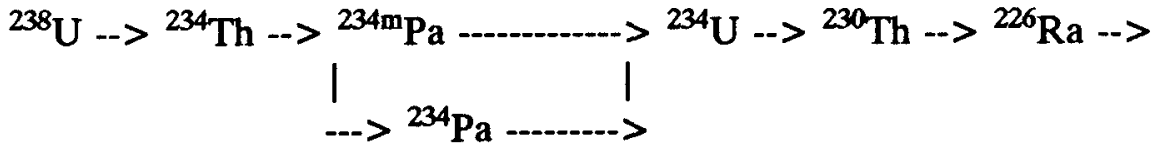

$$
\begin{aligned}
& { }^{222} \mathrm{Rn}->{ }^{218} \mathrm{Po}->{ }^{214} \mathrm{~Pb}->{ }^{214} \mathrm{Bi}->{ }^{214} \mathrm{Po}->{ }^{210} \mathrm{~Pb}-> \\
& { }^{210} \mathrm{Bi} \mathrm{-->}{ }^{210} \mathrm{Po}-->{ }^{206} \mathrm{~Pb} \text { (Stable) }
\end{aligned}
$$

Th-234 $\left({ }^{234} \mathrm{Th}\right)-->\quad$ Half-life: 24.1 days

Emissions: beta, $195 \mathrm{keV}$ max

gamma, $92 \mathrm{keV}(4 \%), 63 \mathrm{keV}$ (3.5\%)

Pa-234m ( $\left.{ }^{234 m} \mathrm{~Pa}\right)->\quad$ Half-life: 1.17 minutes

Emissions: beta, $2.29 \mathrm{MeV} \max$

Pa-234 $\left({ }^{234} \mathrm{~Pa}\right)-->\quad$ Half-life: 6.7 hours

Emissions: beta, $510 \mathrm{keV} \max$

gamma, $100 \mathrm{keV}(50 \%), 126$

$\mathrm{keV}(26 \%), 220 \mathrm{keV}(14 \%)$,

$360 \mathrm{keV}(13 \%), 560 \mathrm{keV}$

(15\%), $700 \mathrm{keV}(24 \%), 900$

$\operatorname{keV}(70 \%), 1.08 \mathrm{MeV}(12 \%)$

U-234 $\left({ }^{234} U\right) \quad->\quad$ Half-life: 247,000 years

Emissions: alpha, $4.775 \mathrm{MeV}$ (75\%),

4.723 $\mathrm{MeV}(28 \%)$

Th-230 $\left({ }^{230} \mathrm{Th}\right)->\quad$ Half-life: $\quad 75,400$ years

Emissions: alpha, $4.688 \mathrm{MeV}$ (76\%),

4.621 MeV (24\%)

(see ${ }^{230} \mathrm{Th}$ for other daughter products) 
MAJOR CHEMICAL FORMS: $\mathrm{UO}_{2}^{2+}, \mathrm{U}^{4+}$ complexes, $\mathrm{UO}_{2}{ }^{2+}$ complexes, $\mathrm{UO}_{2+\mathrm{x}}(\mathrm{s}), \mathrm{NaUO}_{4}(\mathrm{~s})$

PRODUCTION METHODS: Natural

WASTE STREAMS: $\quad$ Reactor wastes fuel fabrication and $\mathrm{UF}_{6}$ conversion plant wastes rare metal processors

MAJOR ENVIRONMENTAL

PATHWAY: $\quad$ Groundwater, air

HEALTH HAZARDS: Ingestion internal dose particularly to bone, lung dose from inhalation, chemical toxicity 
RADIONUCLIDE NAME: Plutonium-239 $\left({ }^{239} \mathrm{Pu}\right)$

HALF-LIFE:

24,110 years

PRIMARY RADIATIONS

AND ENERGIES:

Alpha, $5.50 \mathrm{MeV}(88 \%), 5.11 \mathrm{MeV}(11 \%)$

DAUGHTER PRODUCTS: (Decay chain)

$$
\begin{aligned}
& { }^{239} \mathrm{Pu}->{ }^{235} \mathrm{U}->>{ }^{231} \mathrm{Th}->>{ }^{231} \mathrm{~Pa}->>{ }^{227} \mathrm{Ac} \mathrm{-->}{ }^{223} \mathrm{Fr}->>{ }^{223} \mathrm{Ra}->> \\
& { }_{-\rightarrow>}^{227} \mathrm{Th}-\ldots \\
& { }^{219} \mathrm{Rn} \text {--> }{ }^{215} \mathrm{Po} \text {-.> }{ }^{211} \mathrm{~Pb} \text {-.> }{ }^{211} \mathrm{Bi} \text {-.-> }{ }^{207} \mathrm{Tl} \text {--> stable } \\
& \operatorname{l}_{-\rightarrow}{ }^{211} \text { Po }-> \\
& \text { U-235 }\left({ }^{235} \mathrm{U}\right)-->\text { Half-life: } 703,800,000 \text { years } \\
& \text { Emissions: alpha, } 4.58 \mathrm{MeV}(8 \%), 4.4 \mathrm{MeV} \\
& \text { (57\%), } 4.37 \mathrm{MeV}(18 \%) \\
& \text { gamma, } 143 \mathrm{keV}(11 \%), 185 \mathrm{keV} \\
& \text { (54\%), } 204 \mathrm{keV} \text { (5\%) } \\
& \text { (see }{ }^{235} \mathrm{U} \text { for other daughter products) }
\end{aligned}
$$

MAJOR CHEMICAL FORMS: $\mathrm{Pu}^{3+}, \mathrm{PuO}_{2+}, \mathrm{PuO}_{2}(\mathrm{~s})$

PRODUCTION METHODS: $\quad$ Fission ${ }^{238} \mathrm{U}(\mathrm{n}, \gamma)$

WASTE STREAMS:

Nuclear power plants --> Ion-exchange resins, precoat filters, cartridge filters, concentrated liquid wastes, trash, dry active waste

MAJOR ENVIRONMENTAL

PATHWAY:

Groundwater, air

HEALTH HAZARDS:

Internal exposure to ingested or inhaled daughter products, acute chemical toxicity 
RADIONUCLIDE NAME: Plutonium-241 $\left({ }^{241} \mathrm{Pu}\right)$

HALF-LIFE:

14.35 years

PRIMARY RADIATIONS

AND ENERGIES:

Beta, $20.8 \mathrm{keV} \max (99 \%)$

DAUGHTER PRODUCTS: (Decay chain)

$$
\begin{aligned}
& { }^{241} \mathrm{Pu} \text {--> }{ }^{241} \mathrm{Am} \mathrm{-->}{ }^{237} \mathrm{~Np} \mathrm{-->}{ }^{233} \mathrm{~Pa} \text {--> }{ }^{233} \mathrm{U} \text {-.> }{ }^{229} \mathrm{Th} \text {--> }{ }^{225} \mathrm{Ra} \text {--> } \\
& { }^{225} \mathrm{Ac}->>{ }^{221} \mathrm{Fr} \text {-.> }{ }^{217} \mathrm{At}->>{ }^{213} \mathrm{Bi} \ldots . .>>{ }^{209} \mathrm{Tl} \text {-.> }{ }^{209} \mathrm{~Pb} \text {-.> Stable } \\
& { }_{-\rightarrow{ }^{213} \mathrm{Po} \rightarrow>}
\end{aligned}
$$

Americium-241 ( $\left.{ }^{241} \mathrm{Am}\right)$--> Half-life: 432 years

Emissions: alpha, $5.4857 \mathrm{MeV} \quad \&$

$5.4430 \mathrm{MeV}(98 \%)$ (see

${ }^{241} \mathrm{Am}$ for other daughter products)

MAJOR CHEMICAL FORMS: $\mathrm{Pu}^{3+}, \mathrm{PuO}_{2+}, \mathrm{PuO}_{2}(\mathrm{~s})$

PRODUCTION METHODS: Multiple neutron capture of ${ }^{238} \mathrm{U}\left({ }^{239} \mathrm{Pu}\right.$ and ${ }^{241} \mathrm{Pu}$ are the only fissionable isotopes of $\mathrm{Pu}$ )

WASTE STREAMS:

Nuclear power plants .-> Ion-exchange resins, precoat filters, cartridge filters, concentrated liquid wastes, trash, dry active waste

MAJOR ENVIRONMENTAL

PATHWAY:

Groundwater, air

HEALTH HAZARDS:

Internal exposure to ingested or inhaled daughter products, acute chemical toxicity 
RADIONUCLIDE NAME: Americium-241 $\left({ }^{241} \mathrm{Am}\right)$

HALF-LIFE:

432 years

PRIMARY RADIATIONS

AND ENERGIES:

Alpha, $5.4857 \mathrm{Mev}(85 \%), 5.4430$ gamma, $60 \mathrm{keV}(36 \%)$

DAUGHTER PRODUCTS: (Decay chain)

${ }^{241} \mathrm{Am}->{ }^{237} \mathrm{~Np}->{ }^{233} \mathrm{~Pa}->{ }^{233} \mathrm{U}->{ }^{229} \mathrm{Th}->{ }^{225} \mathrm{Ra}->{ }^{225} \mathrm{Ac}->$
${ }^{221} \mathrm{Fr}->{ }^{217} \mathrm{At} \mathrm{-->}{ }^{213} \mathrm{Bi}->{ }^{209} \mathrm{Tl}->>{ }^{209} \mathrm{~Pb}->$ Stable
$\mid-->{ }^{213} \mathrm{Po}->$

neptunium-237 $\left({ }^{237} \mathrm{~Np}\right)-->$ Half-life: $2,140,000$ years Emissions: alpha, $4.788 \mathrm{MeV}$ (75\%), $4.770 \mathrm{MeV}$ $(12 \%)$ gamma, $29.4 \mathrm{keV}$ $(14 \%), 86.5 \mathrm{keV}$ (14\%), $145 \mathrm{keV}(1 \%)$

(see ${ }^{237} \mathrm{~Np}$ for other daughter products)

MAJOR CHEMICAL FORMS: $\mathrm{Am}(\mathrm{OH})^{3+}, \mathrm{Am}\left(\mathrm{SO}_{4}\right)^{2+}, \mathrm{AmO}_{2}(\mathrm{~s})$

PRODUCTION METHODS: Multiple neutron capture of plutonium-241; ${ }^{241} \mathrm{Pu}$ decays to americium-241

WASTE STREAMS:

Resulting from reprocessing of spent fuel and recycling of uranium and plutonium --> Solidified liquid waste, filters, sludge, trash, and waste from decommissioning smoke detectors and smoke detector manufacture

\section{MAJOR ENVIRONMENTAL}

PATHWAY:

Groundwater (mobility enhanced by complex formation), air

HEALTH HAZARDS: Ingestion and inhalation, internal exposure 


\subsection{Bibllography on Radionuclides}

Adam, J. A. and V. L. Rogers, A Classification System for Radioactive Waste Disposal--What Waste Goes Where, NUREG-0456.

Baker, F. W., D. G. Miller, and F. Feiner, Chart of the Nuclides, Thirteenth Edition, San Jose: General Electric Company, 1984.

Dayal, R., R. F. Pietrzak, and J. Clinton, 1984, Geochemical Investigations at Maxey Flats Radioactive Waste Disposal Site, NUREG/CR-3993.

Eisenbud, M. Environmental Radioactivity--from Natural, Industrial, and Military Sources, Third Edition, Academic Press, 1987.

Jackson, R. E. and K. J. Inch, 1980, Hydrogeochemical Processes Affecting the Migration of Radionuclides in a Fluvial Sand Aquifer at the Chalk River Nuclear Laboratories, NHRI Paper No. 7, Ottawa, Canada.

Kathren, R. L., Radioactivity in the Environment: Sources, Distribution, and Surveillance, Harwood Academic Publishing, 1984.

Kozak, M. W., M. S. Y. Chu, and P. A. Mattingly, 1990, A Performance Assessment Methodology for Low-Level Waste Facilities, NUREG/CR-5532.

Krauskopf, K. B., 1979, Introduction to Geochemistry, Second Edition, McGraw-Hill Book Co., New York.

MacKenzie, D. R., J. F. Smalley, C. R. Kempf, and R. E. Barletta, 1985, Evaluation of the Radioactive Inventory in, and Estimation of Isotopic Release from, the Waste in Eight Trenches at the Sheffield Low-Level Waste Burial Site, NUREG/CR-3856.

Moody, J. B., 1982, Radionuclide Migration/Retardation: Research and Development Technology Status Report, ONWI-321, Office of Nuclear Waste Isolation.

Nuclear Regulatory Commission, 1981, Draft Environmental Impact Statement on 10 CFR Part 61, NUREG-0782.

Oztunali, O. T. and G. W. Roles, 1986, Update of Part 61 Impacts Analysis Methodology: Methodology Report, NUREG/CR-4730.

Roles, G. W., Characterization of Low-Level Radioactive Waste Disposed during 1987 through 1989, NUREG-1418.

Serne, R. J., R. C. Arthur, and K. M. Krupkn, Review of Geochemical Processes and Codes for Assessment of Radionuclide Migration Potential at Commercial LLW Sites, NUREG/CR-5548, PNL-7285, 1990. 
Shipers, L. R. and C. P. Harlan, 1989, Background Information for the Development of a Low-Level Waste Performance Assessment Methodology: Assessment of Relative Significance of Migration and Exposure Pathways, NUREG/CR-5453, Vol. 2.

Stumm, W. and J. J. Morgan, 1981, Aquatic Chemistry: An Introduction Emphasizing Chemical Equilibria in Natural Waters, Second Edition, John Wiley and Sons, New York.

Sullivan, T. M. and C. R. Kempf, 1987, Low-Level Waste Source Term Evaluation: Review of Published Modeling and Experimental Work, NUREG/CR-4897.

U.S. Department of Health, Education, and Welfare, Radiological Health Handbook, Rockville: Bureau of Radiological Health, January 1970.

Wild, R. E., O. I. Oztunali, J. J. Clancy, C. J. Pitt, and E. D. Picazo, 1981, Data Base for Radioactive Waste Management, Vol. 2, Waste Options Report, NUREG/CR-1759.

Still in Draft Form, not issued as of January 1992:

National Low-Level Waste Management Program Radionuclide Report Series, Draft issued December 1991.

Volume 1: Introduction, DOE/LLW-117, M. J. Rudin and R. S. Garcia.

Volume 2: Technitium-99, DOE/LLW-118,'M. J. Rudin, C. Stanton, R. G. Patterson, R. S. Garcia.

Volume 3: Carbon-14, DOE/LLW-119, M. J. Rudin and R. S. Garcia.

Volume 4: Iodine-129, DOE/LLW-120, M. J. Rudin and R. S. Garcia. 


\section{PERFORMANCE ASSESSMENT GLOSSARY}

Acceptance Criteria

Active Maintenance

\author{
ALARA \\ Benchmarking
}

Buffer Zone

Calibration

Code

Concentration

Averaging

Conceptual Model

Curie

Deterministic Model

Disposal
The criteria a product must meet to successfully complete a test phase or meet delivery requirements. (DOE/LLW-102)

Any significant remedial activity needed during the period of institutional control to maintain a reasonable assurance that the performance objectives are met. (10 CFR 61)

As low as reasonably achievable.

Comparison of the computational results of a specific computer code with the results of a reference computer code used to analyze the same or comparable problem (many sources consider benchmarking to be part of verification). (DOE/LLW-102)

A portion of the disposal site that is controlled by the licensee and lies under the disposal units and between the disposal units and the boundary of the site. (10 CFR 61)

Adjustment of the model inputs using alternative combinations of parameter values, within reasonable limits, and comparing model results against observed reference values to achieve reasonable agreement of the model's prediction values with measured values.

A set of computer instructions for performing the operations specified in a numerical method. (DOE/LLW-102)

The practice of combining relatively high concentration waste material with low concentration waste material in the same package with the package concentrations being based on the combined radioactivity divided by the combined waste volume or weight.

A simplified, yet technically credible, picture of the system of interest. (PAW)

The special unit of radioactivity. One curie equals $3.7 \mathrm{E}+10$ nuclear transformations per second. Abbreviated Ci. (DOE/LLW-62T)

A model whose output is fixed by the mathematical form of its equations and the selection of a single value for each input parameter. (DOE/LLW-62T)

The isolation of radioactive wastes from the biosphere inhabited by man and containing his food chains by emplacement in a land disposal system. (10 CFR 61) 
Disposal Site

Disposal Unit

Distribution

Dose Equivalent

Effective Dose

Equivalent

Engineered Barrier

\section{Half-Life}

Inadvertent Intruder

Low-Level Radioactive Waste

Mathematical Model

Mixed Waste

Model

Module
That portion of a land disposal facility which is used for disposal of waste. It consists of disposal units and a buffer zone. (10 CFR 61)

A discrete portion of the disposal site into which waste is placed for disposal. (10 CFR 61)

An empirical measure of sorption, expressed as Kd, Coefficient its equal to the concentration of radionuclide in solid divided by the concentration of radionuclide in solution.

The quantity that expresses the effects of all radiations on a common scale for calculating the effective absorbed dose, the quality factor, and other modifying factors. The unit of the dose equivalent is the rem. (DOE/LLW-62T)

The summation of the products of the committed dose equivalent and weighting factor for each organ, plus the external dose equivalent. (DOE/LLW-62T)

A manmade structure or device that is intended to improve the land disposal facility's ability to meet the performance objectives. (10 CFR 61)

The time required for one-half of any quantity of identical radioactive atoms to undergo radioactive decay. (DOE/LLW-62T)

A person who might occupy the disposal site after closure and engage in normal activities, such as agriculture, dwelling construction, or other pursuits in which the person might be unknowingly exposed to radiation from the waste. (10 CFR 61)

Radioactive waste not classified as high-level waste, TRU waste, spent nuclear fuel, or by-product material. (DOE/LLW-62T)

A representation of a physical, chemical, or biological system by mathematical expressions designed to aid in predicting the behavior of the system. (DOE/LLW-62T)

Waste material containing both low-level radioactive and hazardous components as defined by the NRC and EPA, respectively.

A representation of a real world process. (DOE/LLW-102)

A program unit that is discrete and identifiable with respect to compiling or combining with other units. (DOE/LLW-102) 
Monitoring

Near-Surface Disposal

Pathways

Performance Assessment

Performance Objective

Quality Assurance

Scenario

Sensitivity Analysis

Software Engineering

Source Term

Stochastic Model

Transuranic

Uncertainty Analysis

Validation
Observations and measurements made to provide data to evaluate the performance and characteristics of the disposal site. (10 CFR 61)

A land disposal technique in which radioactive waste is disposed of within the upper 30 meters of the earth's surface.

The potential exposure routes for radiation.

A systematic quantitative analysis of radionuclide release, transport, and dose to man from waste disposal systems to the public and environment, and a comparison of those risks to established performance objectives. (PAW)

Radiologic dose limits or other regulatory constraints (e.g., zero release). (PAW)

A planned and systematic pattern of all actions necessary to provide adequate confidence that the product conforms to the established technical requirements. (DOE/LLW-102)

A conceptual model which represents actions, events, and processes that could result in radiation exposure.

An analysis that quantifies the change in a selected performance assessment measure produced by a change in a specific input parameter or set of parameters. (DOE/LLW-62T)

The systematic approach to the development, operation, maintenance, and retirement of software. (DOE/LLW-102)

The quantity, and type of radioactive material released to the biosphere, usually expressed as activity per unit time.

A model whose output is expressed as a range or distribution. (DOE/LLW-62T)

A radionuclide with an atomic number greater than that of uranium (i.e., 92). All 13 transuranic elements are radioactive and produced artificially.

An analysis that quantifies the uncertainty associated with a selected performance assessment measure induced by the uncertain input parameters. (DOE/LLW-62T)

The process of evaluating software at the end of the software development process to ensure compliance with software requirements. (ANSI/IEEE) 
Assurance that a model as embodied in a computer code is a correct representation of the process or system for which it is intended. (NUREG-0856)

Verification

(1) The process of determining whether or not the products of a given phase of the software development cycle fulfill the requirements established during a previous phase.

(2) Formal proof of program correctness.

(3) The act of reviewing, inspecting, testing, checking, auditing, or otherwise establishing and documenting whether or not items, processes, services, or documents conform to specified requirements. (ANSI/IEEE) 


\section{REFERENCES}

Bear, J. and Arnold Verruijt, 1987, "Theory and Applications of Transport in Porous Media," Modeling Groundwater Flow and Pollution, 1987.

Bonano, E. J., and R. W. Cranwell, 1988, "Treatment of Uncertainties in the Performance Assessment of Geologic High-Level Radioactive Waste Repositories," Mathematical Geology, Vol. 20, No. 5.

Brown, H., 1986, The Low-Level Waste Handbook: A User's Guide to the Low Level Radioactive Waste Policy Amendments Act of 1985, National Governors' Association Center for Policy Research.

Case, M. J., S. J. Maheras, M. D. Otis, R. G. Baca, 1989, A Review and Selection of Computer Codes for Establishment of the Performance Assessment Center, DOE/LLW-83, July 1989.

Case, M. J., and Otis, M. D., 1988, Guidelines for Radiological Performance Assessment of DOE LowLevel Radioactive Waste Disposal Sites, DOE/LLW-62T.

Code of Federal Regulations, Title 10, Part 61, 1983, Licensing Requirements for Land Disposal of Radioactive Waste, January 1983.

Fayer, M. J. and T. L. Jones, 1990, UNSAT-H Version 2.0: Unsaturated Soil Water and Heat Flow Model, PNL--6779, U.S. Department of Energy, April 1990.

Fletcher, C. A. J., 1988, Computational Techniques for Fluid Dynamics, Springer-Verlag, Heidelberg, Germany.

Huyakorn, P. S., J. B. Kool, and J. B. Robertson, VAM2D-Variably Saturated Analysis Model in Two Dimensions, NUREG/CR-5352, HGL/89-01, 1989.

Huyakorn, P. S., and G. F. Pinder, 1983, Computational Methods in Subsurface Flow, 45, Academic Press, Orlando, Florida.

Kozak, M. W., M.S.Y. Chu, C.P. Harlan, and P.A. Mattingly, 1989, Background Information for the Development of a Low-Level Waste Performance Assessment Methodology, Identification and Recommendation of Computer Codes, U.S. Nuclear Regulatory Commission, NUREG/CR-5453 Vol. 4, December 1989.

Kozak, M. W., M.S.Y. Chu, and P.A. Mattingly, 1990, A Performance Assessment Methodology for Low-Level Waste Facilities, U.S. Nuclear Regulatory Commission, NUREG/CR-5532, July 1990.

Low-Level Radioactive Waste Policy Act, Public Law 96-573, December 1980.

Low-Level Radioactive Waste Policy Amendments Act of 1985, Public Law 99-240, January 1986.

Maheras, S. J. and M. R. Kotecki, 1990, Guidelines for Sensitivity and Uncertainty Analyses of LowLevel Radioactive Waste Performance Assessment Computer Codes, DOE/LLW-100, September 1990. 
Napier, B. A. et al., GENII-The Hanford Environmental Radiation Dosimetry Software System, PNL6584 Vol. 1 \& 2, November 1988.

National Low-Level Waste Management Program, 1990, Low-Level Waste Management Handbook Series, Environmental Monitoring for Low-Level Waste Disposal Sites, DOE/LLW-13Tg Rev. 2, U.S. Department of Energy, February 1990.

National Research Council, 1990, Ground Water Models -- Scientific and Regulatory Applications, National Academy of Sciences, National Academy Press.

Nuclear Regulatory Commission, 1988a, Standard Format and Content of a License Application for a Low-Level Radioactive Waste Disposal Facility, NUREG-1199, Rev. 1, January 1988.

Nuclear Regulatory Commission, 1988b, Standard Review Plan for the Review of a License Application for a Low-Level Radioactive Waste Disposal Facility, NUREG-1200, Rev. 1, January 1988.

Rogers V. and C. Hung, 1987a, PATHRAE-EPA: A Low-Level Radioactive Waste Environmental Transport and Risk Assessment Code, Methodology and Users Manual, EPA 520/1-87-028, U.S. Environmental Protection Agency, December 1987.

Rogers V. and C. Hung, 1987b, PRESTO-EPA-CPG: A Low-Level Radioactive Waste Environmental Transport and Risk Assessment Code, Methodology and Users Manual, EPA 520/1-87-026, U.S. Environmental Protection Agency, December 1987.

Runchal, A.K, and B. Sagar, 1989, PORFLO-3: A Mathematical Model for Fluid Flow, Heat, and Mass Transport in Variably Saturated Geologic Media -- Users Manual, Version 1.0, WHC-EP-0041, U.S. Department of Energy, July 1989.

Runchal, A.K., B. Sagar, R.G. Baca, N.W. Kline, 1985, PORFLO - A Continuum Model for Fluid Flow, Heat Transfer, and Mass Transport in Porous Media, Model Theory, Numerical Methods, and Computational Tests, RHO-BW-CR-150 P, U.S. Department of Energy, September 1985.

Sagar, B., and A. K. Runchal, 1990, PORFLO-3: A Mathematical Model for Fluid Flow, Heat, and Mass Transport in Variably Saturated Geologic Media -- Theory and Numerical Methods, Version 1.0, WHC-EP-0042, U.S. Department of Energy, March 1990.

Schroeder, P. R., J. M. Morgan, T. M. Walski, and A. C. Gibson, 1984, Hydrologic Evaluation of Landfill Performance (HELP) Model: Volume 1, User's Guide for Version 1, EPA/530-SW-84-009, U.S. Environmental Protection Agency, June 1984.

Seitz, R. R., S. D. Matthews, and K. M. Kostelnik, 1990, Guidelines for Acquisition, Installation, and Testing of Performance Assessment Software, DOE/LLW-102, U.S. Department of Energy, September 1990.

Seitz, R. R., A. S. Rood, G. A. Harris, S. J. Maheras, and M. Kotecki, 1991, Sample Application of Sensitivity/Uncertainty Analysis Techniques to a Groundwater Transport Problem, DOE/LLW-108, U.S. Department of Energy, June 1991. 
Silling, S. A., 1983, Final Technical Position on Documentation of Computer Codes for High-Level Waste Management, NUREG-0856.

Starmer, R. J., 1988, "Overview of Performance Assessment for Low-Level Waste Disposal Sites," Technical Coordinating Committee Performance Assessment Workshop, El Paso, Texas, November 29. $30,1988$.

Starmer, R. J., L. G. Deering, M. F. Weber, 1988, "Performance Assessment Strategy for Low-Level Waste Disposal Sites," Tenth Annual DOE Low-Level Waste Management Conference, August 30September 1, 1988, Denver, Colorado.

State of California, 1991, State of California Indemnity Selection \& Low-Level Radioactive Waste Facility -- Final Environmental Impact Report/Statement, Prepared by Dames and Moore, Santa Anna, California, April, 1991.

Suen, C. J. and T. M. Sullivan, 1990, "BLT: A Source Term Computer Code for Low-Level Waste Shallow Land Burial," Waste Management 90, Tucson, Arizona, February 25 - March 1, 1990.

Till, J. E. and H. R. Meyer, 1983, Radiological Assessment, A Textbook on Environmental Dose Analysis, NUREG/CR-3332, ORNL-5968, September 1983.

Travis, B. J., 1989, TRACR3D: A Model of Flow and Transport in Porous-Fractured Media, LA-9667MS, UC-32 and UC-70, 1989.

Van Der Heijde, P. K. M., 1987, Quality Assurance in Computer Simulations of Ground Water Contamination, EPA/600/J-87/084, PB-124524.

Wilkinson, G. F. and G. E. Runkle, 1986, Quality Assurance Plan for the Computer Software Supporting the U.S. Nuclear Regulatory Commission's High-Level Waste Management Program, NUREG/CR-4369. 